\title{
Public Spheres, Personal Papers, Pedagogical Practices: Ruth First's Academic Postings to/ from Dar es Salaam and Maputo
}

\author{
Barbara Harlow*
}

\begin{abstract}
This article proposes to consider, in particular, Ruth First's work in her final years at the University of Dar es Salaam (Tanzania) and Universidade Eduardo Mondlane, Maputo, Mozambique (UEM), with reference to her own biographical trajectory and towards a reconsideration of contemporary and subsequent developments in the institutional history of post-independence education: public spheres (the university), personal papers (the archive), and pedagogical practices (the classroom).
\end{abstract}

\section{Résumé}

Cet article se propose d'examiner, en particulier, les travaux de Ruth First pendant ses dernières années à l'Université de Dar es Salaam (Tanzanie) et à Universidade Eduardo Mondlane à Maputo au Mozambique (UEM), en faisant référence à son propre parcours biographique et en vue de reconsidérer les développements contemporains et ultérieurs de l'histoire institutionnelle de l'éducation après l'indépendance : les sphères publiques (l'université), les documents personnels (les archives), et les pratiques pédagogiques (la salle de classe).

\section{From Durham to Dar es Salaam to Maputo to... ${ }^{1}$}

Ruth First, on leave from the University of Durham (UK), spent the fall semester of 1975 teaching in the Department of Economics at the University of Dar es Salaam in Tanzania. The early 1970s were intensely energetic years throughout recently decolonized Africa, and not least so in the

\footnotetext{
* University of Texas at Austin. Email: bharlow@mail.utexas.edu
} 
universities. At Makerere University, for example, radically revised curricula in literary studies would lay the grounds for new imperatives and directions in African cultural production and critical practice. At the University of Dar es Salaam, as at the University of Ibadan (Nigeria), it was historiography and by implication, history itself and its contribution to 'nation-building' that was in question. Ruth First's semester in Tanzania coincided with the presentations, seminars, debates and colloquia across the social sciences faculty of such intellectual upstarts - now luminaries, even posthumously as Terence Ranger, Walter Rodney, Mahmood Mamdani, Archie Mafeje, John Saul, Jacques Depelchin and Issa Shivji.

But if 1975 was an especially active year in post-colonial African intellectual history, it was also another turning point in First's own critical itinerary. South African historian and journalist and, respectively, African National Congress and South African Communist Party (ANC/SACP) activist, Ruth First had left her native country in 1964 with her three young daughters following her release after 117 days of detention to join her husband, Joe Slovo, in exile in London. She would never return to South Africa and was assassinated by a letter bomb sent from Pretoria in 1982 to her office at the Eduardo Mondlane University in Maputo, Mozambique, where she had been a senior researcher at the Centre of African Studies since 1977. That final posting was one that First in fact visited on her return route to Durham from her semester in Dar es Salaam in December 1975/January 1976.

The final half decade of the writer's life was similarly critical to her own intellectual itinerary and no less crucial in the early years of Mozambique's independence, won from Portugal following a protracted and bloody liberation struggle, led by Eduardo Mondlane, the founder of Frelimo - himself assassinated in 1969 in Tanzania - and after whom Mozambique's main university was renamed. First was invited to join the research team at the institution's newly established Centro de Estudos Africanos by its Director, Aquino de Braganca, who himself fell victim to a violent death in the suspicious plane crash in 1986 that also killed Mozambique's president Samora Machel. A memorial stone remembering both Ruth and Aquino stands in the courtyard of the Centro. But that came later. Braganca's invitation was extended to First while she was still in Tanzania and she altered her return ticket to England in order to visit de Braganca and the Centro. Within a year she had assumed her position as Academic and Research Director there. The posthumously published Black Gold: The Mozambican Miner, Proletarian and Peasant (1983) combined her own long-standing interest in miners and migrant labour patterns throughout southern African with the work of her fellow researchers and students at the Centre. Equally relevant to Ruth First's work at the Centre were contributions to curriculum development and the 
design of research agendas and assignments that would facilitate the 'nation-building' project that liberated Mozambique had so recently embarked upon under the Frelimo-led presidency of Samora Machel. Had Ruth First lived even one more decade, she might have gone on to contribute to similar projects in her native South Africa, but her experiences at that critical conjuncture, nonetheless, offer both constructive admonitions and critical aspirations for contemporary projections concerning 'academic exchanges'. The intervening decades, however, have meanwhile heralded both the revisions of neoliberalism and the vagaries of globalization. Whether this is development or not, time has yet to tell. Meanwhile, university curricula remain in flux. Ruth First's academic postings in the crucial transition years in post-independence Africa, from the mid-1970s to the early 1980s, indicate perhaps some of the historical antecedents to contemporary intellectual debates and professorial practices.

\section{Ruth First at the Truth and Reconciliation Commission: Promises and Perils of Academic Exchanges}

I said that she did work with students who were in exile in Mozambique and I said that she was doing major research work assisting the development process in Mozambique. But I did not say that she was not involved in the anti-apartheid struggle. I did not say that she did nothing for the struggle (Mac Maharaj's testimony at the Amnesty Hearings of the Truth and Reconciliation Commission [TRC], 6 November 1999).

When Ruth First's killers applied for amnesty to South Africa's Truth and Reconciliation Commission (TRC), a significant aspect of the commission's deliberations concerned whether or not she was a 'legitimate target', whether, that is, her assassins had acted out of 'political motivation', one of the criteria for amnesty as determined by the 1995 Promotion of National Unity and Reconciliation Act that established South Africa's radical experiment in committing truth. In other words, as ANC-SACP colleague Maharaj's testimony - almost paradoxically, even problematically - would seem to suggest, First's position at the time of her death as research director at the Centre for African Studies should have been decisive in determining that she was by no means a 'legitimate target'. She was, after all, an academic - and at an apparently fledgling institution at that. The TRC's Amnesty Commission, however, decided otherwise, and Ruth First's unrepentant and 'politically motivated' killers were granted the amnesty that they had requested. Academic affiliations may, when all is said and done, not be an excuse after all. But then who is to say? 
Ruth did, after all, as Mac Maharaj testified before the TRC's Amnesty Commission, 'work with students who were in exile in Mozambique' and 'was doing major research work assisting the development process in Mozambique'. Joe Slovo too, Ruth's husband, had already acknowledged as much - and perhaps much more - in his introductory testimony to his wife's work, from her 117-day detention in Marshall Square in 1963 to her death in Maputo in 1982: 'Her selection as a target,' he wrote, 'was neither capricious nor accidental; it served a purpose which, with the passage of time, could be identified more clearly' (Slovo 1988:6). Slovo, who had been controversially critical in negotiating the disputed 'sunset clause' and amnesty process for apartheid's culprits that finally allowed for South Africa's exemplary 'transition to democracy' in 1994, went on in that 1988 introduction: 'Ruth was not working in an ivory tower; the students at the Centre were cadres from the Party and the government, and the dynamism and vigour of the Centre were beginning to influence researchers and scholars from other institutions of learning in Southern Africa' (Slovo 1988:7).

\section{Ruth First in Dar es Salaam}

If less than half a year in a distinguished life-long career as writer and activist, Ruth First's visiting semester at the University of Dar es Salaam is nonetheless crucial both to her own intellectual biography and to that story's relevance for understanding the post-independence African historical narrative and its continued influence. The semester is also especially telling with regard to the early efforts toward post-colonial academic exchanges that sought, however haphazardly, as well as hazardously, to redress even then the distortions of divisions of intellectual labour (in Walter Rodney's terms, perhaps, 'how Europe underdeveloped Africa') that have vexed programmes in international studies ever since.

Ruth First, who at the time was teaching in the Department of Sociology at the University of Durham, was nonetheless interdisciplinarily posted to the Department of Economics at the University of Dar es Salaam, where she would contribute to the emerging curriculum in political economy, such as the second-year course, Economics 202: 'Political Economy of Underdevelopment and Planning'. But first the terms of the exchanges needed to be arranged, terms that involved - no less than did the eventual course syllabi - questions of political economy, underdevelopment and planning. First's assignment, though approved by her institutional administrators in Durham, was importantly mediated and partially financed by the InterUniversity Council for Higher Education Overseas (London), a contemporary instance of current efforts to further international academic exchanges, in this case between Britain and its former colonial, only recently become 
independent, properties. According to the Council's published guidelines, therefore, applicants had to meet the 'research regulations for foreign scholars' in African countries. In Tanzania, these regulations were explicitly and emphatically articulated in the University of Dar es Salaam Calendar for 1971-72 and cited as such in the Council's brochure:

ALL applications for permission to conduct research MUST be channelled through the University of Dar es Salaam [...]. If the candidate and research project meet the approval of the University and the Government, Research Associateship will be bestowed upon him or her. This process may take several months, depending upon vacation periods during which various University approving bodies do not meet. "Only research projects which are beneficial to the university and the country will normally be considered" ... (Emphases in original). ${ }^{2}$

How 'beneficial', however - and to whose benefit, when, where - would Ruth First's research and teaching contributions in the Department of Economics at the University of Dar es Salaam be found to be anyway?

Ruth First's application did go forward, if in fits and starts, and she eventually arrived in Dar es Salaam in late August 1975 to take up her temporary teaching position at the university some eight years after Nyerere's pronouncement of the Arusha Declaration in February 1967 that outlined the Tanganyika African National Union (TANU)'s policy on 'socialism and selfreliance' for Tanzania. First she had been living in London since early 1964 where she had resettled, following her release from South African detention, raising her three daughters and managing the household during the often protracted absences of her husband, Joe Slovo, whose work with the ANC took him regularly to Africa. Her own already distinguished career in South Africa as an ANC/SACP anti-apartheid activist and investigative reporter was critically transformed over the course of her London expatriation, under both political and financial pressures; there was, in other words, a struggle to be waged and a family to be supported. Bills had to be paid after all, debts accounted for, old scores settled, and freedom won. Prior to taking up her post at the University of Durham in 1973, then, First had already published (or researched) numerous books, on South West Africa (1963), Libya (1974), coups in Africa (1970), sanctions against South Africa (1972), and her own prison memoir, 117 Days (1965), and her credentials as a researcher were academically impeccable if politically, and probably just as predictably, controversial. She would go on to publish several more books, including Olive Schreiner (1980) and the posthumous Black Gold (1983). ${ }^{3}$ Whatever then could the former South African political detainee, journalist, professor, public speaker, rally crier, exile, possibly be doing in Dar es Salaam in 1975? 
According to the Arusha Declaration, advocating as it did policies of socialism and self-reliance, and perhaps with particular and exemplary relevance for reconstituting academic endeavours and enterprise in the newly independent nation, the 'biggest requirement (for development) is hard work', but, the Declaration admonishingly continues, 'the second condition of development is the use of intelligence. Unintelligent hard work', emphasised Nyerere's Declaration, 'would not bring the same results as the two combined'. Although Ruth was most certainly intelligent, and it would be difficult, even for her critics, to deny that she was a hard worker - on any number of fronts - there were still the requisite bureaucratic and political protocols attaching to the Durham-Dar exchange that needed to be worked out before the deal could be done. For example, as one Dar es Salaam colleague wrote to First regarding the possibility of establishing 'some sort of interdepartmental link' between the two institutions, 'the more good postgraduates you can send the better but they will have to learn Swahili' (David Rosenberg to Ruth First, 8 June 1974). Nor was the language facility the only issue. Shortly afterwards, First wrote back to Rosenberg regarding monetary, costbenefit, arrangements: 'Since the suggestion for the inter-departmental links organised with the Inter-University Council, we are at present exploring the financial aspects of such an exchange, and the possibility that the Council might finance the secondment of teaching staff from here to your Department, so that you would not be burdened with any additional financial cost but, on the contrary, would benefit to the extent that you want additional teaching....' (RF to David Rosenberg 26 August 1974). But there were political investments as well that would be at stake. Rosenburg wrote, for example, that 'we are extremely keen on bringing here people who have worked on Cuba, China, West Africa, etc, etc' (24 October 1974). Two months later, as the prospects for the exchange evolved, First herself would reply to university administrator, Dr. Justinian Rweyememu, regarding both her intellectual interests and her academic bona fides, that, as she wrote, 'my strongest concerns and interests are in Africa, both independent Africa and the South, though I have been teaching across a broadly comparative Third World board' (28 December 1974). Her teaching and research interests, and her political commitments too, would seem to have qualified Ruth First for the opportunity to join for a semester the faculty in the Department of Economics at the University of Dar es Salaam, even if, as her head of department in Durham, Philip Abrams, wrote to her in June 1975, 'I suppose the invitation is a Good Thing, although I must say it will cause some problems. I will start now', Abrams nonetheless went on, 'to unravel the administrative tangles if any. After all, since 'we want,' he wrote, 'a special relationship with Tanzania I suppose we really should take the opportunity to bring it to life if we can' (6 January 1975). 
Within a matter of months, Ruth would be in Dar es Salaam, where Arushaprovoked crises still simmered on the campus - and intellectual excitement continued to ferment.

The Arusha Declaration was later, indeed with more than twenty years' hindsight, described further by Isaria Kimambo, a historian and Chief Academic Officer of the University of Dar es Salaam at the time of Ruth First's assignment there, as outlining the design to 'build a socialist state in Tanzania under the principles of socialism and self-reliance'. As Kimambo goes on, in his discussion of 'three decades of production of historical knowledge at Dar es Salaam', the 'impact of the Declaration was great in all Tanzanian societies. But it was even greater on the University community in Dar es Salaam because the community itself was in a serious crisis and it appeared as if the Arusha Declaration was responding directly to the prevailing crisis' - a crisis that had ensued from the government's decision to 'introduce National Service in order to prepare educated youths for service to the nation' (Kimambo 1993:3-4). That crisis is recounted still another decade later in a study conducted by the Partnership for Higher Education in Africa, Higher Education in Tanzania. The 'crisis' for an institution that had, according to the study's historical background to its analysis and recommendations, 'acquired a reputation for scholarship that espoused causes and issues related to liberation, social justice and economic development' (Mkude et al 2003:3), that crisis is examined by the international reviewers as due, at least in significant part, to the fact that the 'measures to reorganize the university to make it responsive to the needs and aspirations of the people of Tanzania were not always well received' (Mkude et al 2003:4). By the time Ruth First arrived in Dar es Salaam, however, in August-September 1975, the crises seemed to have been - perhaps temporarily, and if only too tenuously - resolved.

First was, in the early days of her semester-long sojourn at least, especially impressed with the 'Africanisation' of the university and the programmatic priority, the crises notwithstanding, given to the matriculation of 'mature' students. As she wrote reflectively and speculatively to her husband Joe shortly after her arrival, on 3 September, 'I'm amazed at the level of my students, though I'm sure there are duds and conservatives among them too. But this is the first year of the mature intake i.e. university entrants are no longer processed through the schools but through the workplaces, and need Tanu credentials. From the looks of it numbers of older people, experienced people have got in, and their commitment is very earnest, even if only for careers'. Parenthetically, however, she continues: '(One negative effect is that the intake of women dropped from 10 to 2.5 per cent; a reflection of the discrimination against women in life after high school...)' 
(RF to Joe Slovo, 3 September 1975). A short month and a half later, however, the same teacher of the second half of the year-long Economics 202: Political Economy of Underdevelopment and Planning, would write, if not less enthusiastically then still rather more critically, to her daughter Gillian:

My students are complaining that in the essay assignments I've set them as 40 per cent of the exam mark - they have to read more than one book. More explicitly they are open-ended questions: they complain, they have to think out an answer: and a direction of argument: Surely some will take to it well: many are very bright, though instinctively set for conservatism once this university training guarantees them a meal ticket for life, which it will.

What gets me is when, in conversation or in class, some of them try putting over this socialist ethos thing: an official line that carries less and less conviction as they proceed to pretend bureaucrats and workers and peasants alike have their shoulder to the socialist wheel

The workers term for the bureaucrats is the Nizers: those who have never looked back since they were Africanized into the controlling posts of the system (20 October 1975).

The course assignments for Economics 202's second term, as identified on the syllabus, are, however, indeed demanding, organized under the topics of 'theories of underdevelopment', 'strategies of development', 'industrialization', 'rural questions', 'rural co-operation in Tanzania', and 'class and development', with readings ranging from the classical works of Marx and Lenin through contemporary critics such as A.G. Frank, Samir Amin, E. Laclau, H. Alavi, and I. Shivji, to cite but a few examples.

First herself was not unconcerned at the kinds of academic exchanges that were enabled - or disabled - by her own relative newness to the situation and the challenges of the experiment in higher education launched in the early years of the University of Dar es Salaam and into which she had entered. Her lecture notes for the introductory session are provocatively suggestive of the pedagogical imperative she worked under in this historic setting:

Today an introd lecture by way of exploration

Find my feet, find out where yours are, for we have to run this course together!

Difficulties of not being with you right from outset unavoidable

My purpose today: to check where you are.

The notes go on:

MAIN purpose: to draw some threads together 
Provide an overview which does not repeat the theories of development, underdevelopment, but which slots them together, for they do make a pattern.

First also admonished and encouraged her students about the 'importance of feedback', noting to her students:

Hope you'll speak up, even dissatisfaction, complaints. Lectures pack too much? Too thin? Coming over too fast? [...] Interruptions (questions) during lectures? You must judge. Break continuity - danger. Throw me off my balance? On the other hand sometimes helpful to ask for clarification. And if I can't give it at the time I promise to go away and think about it for the following time.

As for the seminars, these are to be 'working sessions', she emphasizes to the students. 'YOU to do the work.' For that first, introductory, lecture, the teacher's notes run to fifteen typewritten, handwritten, much redacted pages. Ruth First was, as she wrote at the time to her Durham colleague and friend, Gavin Williams, 'flushed with elation at the experience of development having relevance' (16 September 1975).

The final exam questions that First set, following meticulous revisions and painstakingly cramped rewritings, for the students of Economics 202 not only ask the exam-takers to respond to the concerns of the syllabi, but also perhaps to summon a critical analysis, even if not an elated one, of the 'experience of development having relevance'.

Answer Three (3) Questions, 1 (one) from Section A and two (2) from Section B.

Section A

1. Outline and evaluate 'vicious circle' explanations for poor economies.

2. Outline and evaluate Rostow’s Stages of Growth theory.

3. Distinguish between 'growth' and 'development'.

4. What factors explain the expansionist tendencies of capitalism (a) in the period of the scramble for Africa in the late $19^{\text {th }}$ century and (b) in the post-independence situation of the second half of the $20^{\text {th }}$ century?

\section{Section B}

5. 'For capitalism to penetrate into the sphere of industrial production it must have a market which is ready to absorb a continuously increasing volume of products'. What obstructs this process in under-developed economies? 
6. Explain Samir Amin's theoretical model for self-centred (developed) and dependent (peripheral) capital accumulation.

7. 'In under-developed economies the state performs the function of merchant capital'. How would you substantiate this statement from the characteristics of merchant capital?

8. 'Industrialisation can deepen under-development'. Demonstrate this with reference to the case of Tanzania, giving careful and accurate instances of the trends in industrialization policy since Independence.

9. 'External dominance' is only possible where it finds support in national sectors which benefit from it'. Is this statement valid in the case of Tanzania OR Kenya?

The very questions that Ruth First posed to her Economics 202 students at the end of the 1975 academic year, and at the conclusion of her own semesterlong academic exchange, at the University of Dar es Salaam, were indeed pressing questions, not only for her students, who must needs pass at least the exam if not the hurdles awaiting them in the public sphere, but for the researchers, colleagues, policy-makers and politicians, Tanzanian, African, international alike, with whom she shared and disputed the intellectual premises and academic corridors and offices. The same questions, that is, animated importantly the discussions among the 'intellectuals on the hill', as Issa Shivji referred to his colleagues on the campus, or critics - both positive and negative - still identified in the literature as the ground-breaking 'Dar es Salaam school of historiography'.

For now, however, which Economics 202 exam question(s) would you want to try to answer? Then? Currently? Or which of the interrogatory puzzles might Ruth First herself have been most keen to investigate at the time? Would question four, for example, among the options under Section A, be considered as timely, anachronistic, or even, just perhaps, prescient, asking as it does after a longer historical narrative that would connect critically the 'expansionist tendencies of capitalism (a) in the period of the scramble for Africa in the late $19^{\text {th }}$ century and (b) in the post-independence situation of the second half of the 20 $0^{\text {th }}$ century'. Beginnings and ends, not to mention means, were implied in the exam question. Ruth, whose own bibliography extends from her early reporting on the 1946 mine strike in South Africa to the posthumously published study of migrant mine labour, Black Gold, had herself left unfinished a project on the 'profile of a corporation', identifying in her notes both Anglo American and the Suez Canal Company as possible case studies. Reflecting back on that particular period - when Ruth First set those exam questions - of the university's history, however, Kimambo 
considers in 1993 that, 'from the historians (sic) point of view, the two decades of debating theory did mean lost opportunity to produce historical knowledge for almost a whole generation' (Kimambo 1993:15). The problem, it seems, was twofold: 'first, concentration on theory and second, directing most of the research to the colonial period' (Kimambo 1993:17). According to Kimambo, 'We can congratulate ourselves for having found research tools for producing the kind of knowledge required for a socialist society. But do we now have a socialist society?' (Kimambo 1993:19). Another decade and a half later, when the very vision of that socialist society itself might well seem almost altogether an historical artifact, having yielded ground to structural adjustments and donor-driven international interventions, yet another historian raised similarly vexing questions about the misconceived fixation on colonialism. What, asks Frederick Cooper, is one to make of this 'burst of scholarship on colonial studies in the last two decades - crossing the disciplinary boundaries of literature, anthropology, and history - [that] has begun to fill one of the most notable blind spots in the Western world's examination of its history. Yet,' Cooper goes on, 'there is something strange about the timing: scholarly interest in colonialism arose when colonial empires had already lost their international legitimacy and ceased to be viable forms of political organization. Earlier, when colonialism was an object of mobilization, scholars and intellectuals were most captivated by the drama of liberation movements and the possibilities of "modernization" and "development" for people whom colonialism and racism had excluded from the march of progress' (Cooper 2005:3). Why was Ruth First, in other words, so very caught up in the 'drama of liberation movements' and 'flushed with elation at the experience of development having relevance', asking her Economics 202 students about colonialism on their final exam, to comment on the "scramble for Africa" - of all things? Jacques Depelchin, who also was in Dar es Salaam at the time of Ruth First's academic exchange and again as a colleague in Maputo at the Centro de Estudos Africanos, has since commented trenchantly on the precarious renewal of the persistent relevance of the "scramble for Africa". According to Depelchin, that is, the "history of the continent, like the continent itself, ha[s] been partitioned by the scholars: everyone carving their field, not in terms of the populations they were studying, but in terms of their interests, debates and controversies...' (Depelchin 2005:37).

\section{Mozambique! Wow: Ruth First in Maputo}

Meanwhile, back in Durham following her semester in Dar es Salaam, First presented a course that built on her newly-grounded understanding of postindependence Africa generally and the case of Tanzania in particular. In 
notes drafted toward 'Some attempt to sum up Tanzania', she is still interested in colonial history and its continued sway in the 'postcolony': 'at Independence,' she notes, 'Tanzania is not disengaged from the international economy,' and elaborates a few pages later: 'So the changes in political forms, structures, need not be decisive. Independence brings the withdrawal of the colonial state apparatus. But the new political forms did not achieve a disconnection from the world economy, nor any substantial change in the way it is connected via the supply of raw materials, to which you add also the purchase of tecnology (sic), expertise, debt servicing on aid.'

First's brief sojourn as a visiting scholar at the University of Dar es Salaam, late in her violently foreshortened life as it turned out to be, was perhaps nonetheless, if not all the more, critical to the activist-academic's biobibliography. Shortly after her arrival in Dar, for example, Ruth had written to her husband Joe, as if in reconsideration of her peripatetic ways, errant critical perspectives, and wayward intellectual commitments: ' ...I'm actually too tired tonight to do more than chatter. But,' she continued almost poignantly, 'I'm also homesick for you all, though I know you won't be convinced. You'll have visions of palm fringed shores, which there are, and pawpaws, a glimpse of which I caught in a fruit salad tonight, but I don't think I still feel adventurous about striking out alone in foreign places, and with a heavy workload, and I keep thinking back to London and Lyme Street, the angstand-drang of four women tangling nonetheless...' (15 August 1975). Just two months later, however, on 15 October, she wrote to Joe again, with a very different critical perspective, perhaps still more errantly wayward: 'Mozambique. I've heard that they (the University people planning a Centre of African? Southern African? Studies (I'm not sure which) want me to come to LM [Lourenco Marques] for a short visit. I may say I'm thrilled to bits. Tanzania is one thing, but Mozambique! Wow' (15 October 1975).

Ruth First took up her post at Centro de Estudos Africanos in 1977 and continued her work there as researcher and research director until, at last, she opened that fatal letter sent from South Africa in her Maputo office late in the afternoon of 17 August 1982, just before a celebratory toast to a successfully completed academic conference that she had helped to organize. Mozambique. Wow. Indeed. But was Ruth First a 'legitimate target' for South Africa's assassins? According to her husband, Joe Slovo, writing some six years after her death in the introduction to the re-edition of her prison memoir, 'Ruth had brought to her post at the Centre a rare combination of gifts: a razor-sharp intellect, a flow of language which enabled her to communicate complex ideas simply, a deft organizational talent, an ethic of meticulous preparation, and an approach to teaching which firmly situated the student in society" (Slovo 1988:4). A ‘legitimate target', after all? Perhaps. 
The Centro de Estudos Africanos was a major intellectual and politically attuned academic innovation of Mozambique's post-independence experiments in higher education. Aquino de Braganca, the Centre's Goanborn director who had invited Ruth First to join him and his colleagues in their probing endeavours, was hailed, on the occasion of his own suspicious death in 1986, by African historian Basil Davidson as the very 'heart and sinew of those struggles'. According to Davidson, in an appealing obituary to his comrade in academic arms, 'The eventual historians of the liberation movements of Mozambique, Angola and Guinea-Bissau will find him, when their moment comes, at almost every passage of those complex years' (Davidson 1987:260). Meanwhile, in the late 1970s and early 1980s, the scholars and students at the Universidade Eduardo Mondlane were already drafting the outlines of those passages - in the syllabi and readings for the prescribed, team-taught Curso de Desenvolvimento (or 'development course'), in the journal Mozambican Studies/Estudos Mocambicanos, and through the quarterly newsletter Southern Africa Dossier/Dossier Africa Austral. Ruth First, before her proverbially untimely death, contributed significantly, if occasionally critically, to each of these several endeavours. The exiled South African's final, posthumously published, book - Black Gold - was already strongly represented in and through the work of the Centre, drawing as it did on the shared field work and theoretical constructions of her colleagues and students. Indeed, as she had written to herself in the notes for her introductory lecture to Economics 202 back in Dar es Salaam, she would have had to 'find my feet, find out where yours are, for we have to run this course together!' But there were too always those same 'Difficulties of not being with you right from [the] outset'. And just maybe question 4, from section A of Economics 202's final exam, would have influenced in some way the evolving, collectively concocted, syllabus of the still exemplary Curso de Desenvolvimento: 'What factors explain the expansionist tendencies of capitalism (a) in the period of the scramble for Africa in the late $19^{\text {th }}$ century and (b) in the post-independence situation of the second half of the $20^{\text {th }}$ century?' Both the pressing demands of immediate agendas and the prevaricating disputes over narratives of longer durées came inevitably into play.

The Centro's 'development course' was, and would remain, itself a workin-progress, developed and debated over the years by the staff - and students - of the programme. Its main themes - as identified in the 'notas de ensino' (or teaching notes) for the years 1979-1983 - specify, in general terms, world economy, with a sub-topic on colonial capitalism; class and state in Africa; empirical methods; and theories of capital. In a section on 'economia mundial: capitalismo colonial', for example, questions of the international 
division of labour would be addressed, together with the issue of economic and financial dependency, along with assigned readings from Eduardo Galeano, Samir Amin, Walter Rodney, Ernest Mandel and Harry Magdoff. There was particular emphasis too on the problems of periodisation, as in the section on 'some considerations of pre-colonial Africa', which narrated a process from the slave trade through informal to formal colonialism. Geopolitical comparisons were drawn out with neighboring Tanganyika (Tanzania), as well as Kenya and Ghana, and concluding emphasis was on the situation of Mozambique itself, as exemplified in one of the 'metodos empiricos' sections that focused on the 'processes of economic growth and restructuring', demanding, first, a statistical analysis of the industrialization process in Mozambique, and second, a discussion of the restructuring of the country's cotton sector in the period 1960-1973. Supplementary readings ranged from Lenin and Rosa Luxemburg to contemporary essays and analyses by the Centre's affiliates and position papers from Mozambique's ruling party FRELIMO. The Centre was, after all, and as it was described in the introduction to the first issue of Mozambican Studies/Estudos Mocambicanos, a 'research and research-training institute' (de Braganca and First 1984:3). Ruth First and Aquino de Braganca elaborated further still on the Centre's mission in their editorial introduction to the inaugural issue, entitled 'Underdevelopment and Migrant Labour': 'The independence of Mozambique,' they wrote, 'made necessary and inevitable the total reconstruction of Mozambique's history,' believing, they argued, that 'the making of a revolutionary history requires more than the mere presentation of a contrary version of the events, and more than a descriptive account of anti-colonial resistance and rebellions mounted by Mozambicans against the colonial power' (de Braganca and First 1984:5). Both editors, however, would die within just four years of each other. Even so, the challenge to the intellectual, for the academic, from the material conditions and historical conjunctures, raised by their conflicted engagement with periods of conflict and post-independence policy-making, resonated roundly and resoundingly, if at times contradictorily. What, really, was an intellectual to do?

'In history as in any other science,' according to the 1986 reflections of Aquino de Braganca and CEA colleague Jacques Depelchin on the 'idealization of Frelimo' and its consequences for the 'understanding of the recent history of Mozambique,... it is, at times, necessary to track back and question the knowledge which is considered definitive. In the case of Frelimo this does not mean going back on the question of the chosen objectives. It is a question of analyzing how the journey was achieved, and of analyzing if the manner in which it has been recounted has not generated errors of comprehension, errors of knowledge.' There is - or was, according to de Braganca and 
Depelchin, a 'teleological problematic' (de Braganca and Depelchin 1986:166), a problematic raised a year earlier by yet another South African CEA colleague, Harold Wolpe, in his contribution to the debates section of the London-based Review of African Political Economy (on whose editorial board Ruth First served). What, Wolpe had asked, should be the 'critical role of researchers who are not opposed to a regime [such as Mozambique’s Frelimo-led government], but, in fact, are organically connected to its goal of social transformation?' (Wolpe 1985:72). The very choice of 'research issues' was itself over-determined, as Wolpe argues, given the 'relationship of the centre to Frelimo and the party and [that] the state was the product of a struggle both within the centre and the party and between them' (Wolpe 1985:75). Journeys, objectives, goals, products, struggle. A teleological problematic indeed.

The 'work of a young new school of Mozambican historians', announced by First and de Braganca in the first issue of Mozambican Studies, was charged with nothing short of the 'total reconstruction of Mozambique's history', in other words, the 'making of a revolutionary history' (de Braganca and First 5), a narrative in which 'periodisation' must be radically distinguished from mere 'chronology' (de Braganca and First 1986:6). Although the research emphasis would be on 'developments after 1885', the year of the Berlin Conference (or, if you will, the 'scramble for Africa'), the CEA's revolutionary history was, that is, of necessity, 'more than the mere presentation of a contrary version of the evens, and more than a descriptive account of anti-colonial resistance and rebellions mounted by Mozambicans against the colonial power' (de Branganca and First 1986:5). But that was then, in the early, buoyant even heady, days of Mozambican independence. Today, according to the report from Partnership for Higher Education in Africa, Higher Education in Mozambique, the country's total higher education student population (in both national and private institutions) is nearly 11,000 students. In 1978, just after Ruth First's arrival at the Centro, there had been just 750 students in toto (Mario et al 2003:8). According to the report, in its recapitulation the 'historical background' of Mozambican higher education, the early challenges were daunting, if not overwhelming: 'To justify its existence, the university adopted a utilitarian stance, training human resources for what were considered to be the pressing needs of the new socialist economy' (Mario et al 2003:8). The editorial introduction by Aquino de Braganca and Ruth First to the second issue of Mozambican Studies/Estudos Mocambicanos, however, insisted still on the crucial importance of historical 'periodization', or, in other words, that snarly 'teleological problematic'. Entitled 'From Chibalo to the Liberation of South Africa', the arguments presented in the issue (published two years after 
Ruth's assassination and two years before Aquino's death) - in articles on chibalo (forced labour), cotton production, migrant labour, and the Angolan counter-revolutionary, Jonas Savimbi - sought to 'analyse the workings of colonial-capitalism, not as any indulgence in a dead past but in the service of the transformation of society by the Mozambican revolution'. Geography was to be no less decidedly consequential than historical periodization, for the issues of migrant labour implicated researchers 'not only within Mozambique but in Southern Africa as a whole' (de Braganca and First 1986:2). In other words, as her husband Joe has written of his wife's work in Mozambique, 'Ruth was not working in an ivory tower: the students at the Centre were cadres from the Party and the government, and the dynamism and vigour of the Centre were beginning to influence researchers and scholars from other institutions of learning in Southern Africa' (de Braganca and First 1986:7).

'Between the mid-1970s and early 1980s,' according to legal scholar Boaventura de Sousa Santos, 'this [developmentalist] model of the state entered into a crisis. It was during this transition period, in 1975, that the countries freed from Portuguese colonialism - Mozambique, Angola, GuineaBissau, the Cape Verde Islands, and Sao Tomé and Principe - emerged, and all of them, without exception, adopted the socialist path to development' (Santos 2006:42-3). Times - and academic agendas and affiliations with them - would change, under multiple pressures, whether local, regional, continental or international. The role of the university in developing and/or determining political processes remains in question. If not lives, at the very least livelihoods, are still part of the calculation. Former colleagues of Ruth First in the Dar es Salaam of yore, in 1975, have since suggested new accountings

\section{What Now? What? Now?}

'In societies like ours,' writes Issa G. Shivji, once a young colleague of Ruth First and now distinguished professor of law at Tanzania's University of Dar es Salaam, societies, that is, 'which have still to find a firm direction of development, which have still to evolve a nation and a national vision, the overplaying of partisan politics can have debilitating effects' (Shivji 2006:156). According to Shivji, then, '[w]e therefore need more than other societies the kind of bodies and institutions which can rise above partisan politics and concern themselves with larger social and national issues. A student body as part of an intellectual body - is one such group' (Shivji 2006:156). 'Intellectuals in Politics' is but one - albeit telling - chapter in the law professor's collection of dedicated columns from three Tanzanian newspapers published between 1990 and 2005, Let the People Speak: Tanzania Down 
the Road to Neo-Liberalism. Shivji's commentaries, published by the Council for the Development of Social Science in Africa (CODESRIA) are complemented by another CODESRIA volume, authored by Mahmood Mamdani, currently at Columbia University but whose own academic career began at Makerere University and the University of Dar es Salaam as a colleague of Issa Shivji and Ruth First. Scholars in the Marketplace (2007) is a case study of the 'dilemmas of neo-liberal reform at Makerere University' - another, neighboring, 'intellectual body' - from 1989 to 2005.

Mamdani and Shivji are each similarly - if with different emphases invested in re-reading recent post-independence histories of East African nation-making experiments, at once academic and constitutional. Whereas Scholars in the Marketplace is, as the author describes it, a 'case study of market-based reform at a single university in Kampala, Uganda' (Mamdani 2007:vii), Let the People Speak collates some 90 essays in combined chronological/thematic order towards an 'intellectual history of the transition' from nationalism to neo-liberalism in Tanzania, with reference in particular to constitutional contests, multi-party politics and academic freedoms. Together, however, the two volumes are demanding provocations for scholars and students to retake politically, actively, the more than 'academic' questions of academic relevance and intellectual contribution to the politics of race and class in East Africa specifically, but with, once again, more than generalised consequence for globalising programmes in higher education.

In introducing his 'case study' of Makerere University, Mamdani describes his own involvement in the project: 'I wrote,' he tells the reader, 'this book for two reasons: a commitment to Makerere as my home university, and a conviction that research must be an integral component of higher education, particularly in countries with a recent colonial past' (Mamdani 2007:xii). While colonialism - and its neo-colonial successors - looms large indeed in identifying and underwriting the 'dilemmas' challenging Makerere University, it is that other nefarious success story of 'neo-liberalism' that is writ just as brazenly and every bit as cravenly across the screeds and scrolls of academic endeavour internationally. In other words, Scholars in the Marketplace is recommended reading for all 'scholars in the marketplaces' of international contemporary higher education.

Mamdani nonetheless remains scrupulously focused on the Makerere example - and its exemplary position in the African historical narrative: 'Uganda,' he notes, setting the early record straight, as preliminary to its subsequent deviations, 'was exceptional among British twentieth century colonies to have a resident university. Makerere University, first established as a vocational school in 1922, was envisioned not as a national university, but as a university for Britain's East African colonies.' Following Ugandan 
decolonization in 1962, the institution turned to the 'training of human resources for the newly independent nation' (Mamdani 2007:1) Mamdani's shorter narrative - the decade and a half from 1989 to 2005 - is, in turn, concerned rather with the intellectual changes wrought by the broader national prioritisations from 'knowledge-driven' to 'market-driven' economies, prioritisations initiated by the international financial institutions (IFIs) such as the World Bank, and the combination of reallocation of resources to primary education and the privatisation/commercialisation of the once research-oriented university. Drawing on a meticulously close reading of academic records, committee minutes, departmental documents, personal testimonies, collegial combat narratives, administrative abdications, and governmental capitulations, Mamdani constructs a compelling, indeed riveting, saga of institutional transformation and national genuflection to the coercions of neo-liberal agendas. At stake, in particular, were the disciplines themselves, who sold out to the marketeering of a putative inter-disciplinarity, when, 'rather than enriching disciplinary competence, the inter-disciplinarity born of a highly commercialised institutional culture eroded it,' and research was forsaken for vocationalism, with market-orientation tending to 'reproduce uncritically the distortions of the market, especially those historically created through a colonial experience' (Mamdani 2007:212-3).

Shivji is no less forthright in declaring his critical commitments to his topic, particularly in his account of Tanzania's shift from the 'villagisation' proposed and practised by independent Tanzania's first president, the late Julius K. Nyerere (or 'Mwalimu' [teacher], as he was known and as Shivji refers to him) to post-independence 'globalization': 'I am particularly fascinated,' Shivji writes to his readers of one of the columns in the chapter that describes how Tanzania went 'down the road to neo-liberalism', 'by the symbolisms and representations of the two periods. Allow me to share my indulgence with you. In the process, if I become nostalgic, bear with me. For I cannot plead any neutrality with respect to the first period. As a youthful militant, I was a full participant in it, and as a participant I cannot help being nostalgic, and, perhaps, subjective' (Shivji 2006:195). Let the People Speak surveys, over the course of a decade and a half - the same period reviewed by Mamdani with respect to Uganda's Makerere University - Tanzania's post-independence story and its constitutional history.

Shivji's 'intellectuals in politics' are centrally placed in the fifth of the ten chapters that are organized to identify both a chronology (periodisation?) and the issues that have hallmarked that particular narrative and its main protagonists - and antagonists - in the drama of what Shivji names as still another African AIDS syndrome: African Intellectual Dependency Syndrome, a 'democratic package' of human rights, free markets, and good governance 
that rewraps the previous 'colonial package' of Christianity, capitalism, and state law. These overlapping and overriding episodes are adumbrated in Shivji's introduction: 1964 and the union of Zanzibar and Tanganyika, the era of Nyerere's Arusha Declaration and its proclamation of socialism and self-reliance (ujamaa), 'Mwalimu’s last term' (1980-85), followed by the period in question: the 'rise and consolidation of neo-liberalism', from 1990 to 2005. Shivji's organization of these assorted news commentaries - many of which emerged from various party congresses and constitutional debates - provides a challengingly critical account of Tanzania's riddled recent history, although, as he also notes, the "relationship between the "town" and the "gown" is an interesting component of the intellectual of the country, which should be told some day in its own right'. More 'scholars in the marketplace'? Or...? Shivji, whose earlier volume, Intellectuals at the Hill: Essays 19691993 (1993), documented even then the author's 'call for a committed intellectual' at the Hill, as the University of Dar es Salaam is still known, like Mamdani, is emphatic in his insistence on the imperative to 'cross-examine mageuzi [change] itself. It needs to be interrogated,' he continues. 'Politicians may manipulate mageuzi, demagogues may worship it, but it behoves [sic] the intelligentsia to question it' (Shivji 2006:128).

How, then, will the 'scholars in the marketplace' regroup to 'let the people speak' - if that is indeed what is to be called for? For Mamdani, 'Even if we should conclude that the cost of setting and running [a research university] is too high for a small and poor country like Uganda to bear alone, that should be reason to explore alternatives on a wider scale, including a possible return to the earlier idea of a University of East Africa" (Mamdani 2007:268). Shivji too champions the need for new returns, but, he concludes, 'The forces that would crystallize the Pan-Africanism of the Left have yet to come together. The seeds of such forces are being planted in the antiglobalisation movement...' (Shivji 2006:303). Back to the books, then as now, as nothing short of a call to arms...

\section{No End in Sight, or a Teleological Problematic}

More than a quarter century now has passed since Ruth First was killed by the letter bomb which she opened in her office at the Centro de Estudos Africanos at Mozambique's Universidade Eduardo Mondlane. Her murderers were amnestied a decade ago as part of South Africa's all-too fabled 'transition to democracy'. On the twenty-fifth anniversary of their colleague's death, however, a conference was organized by current teaching and research staff at the CEA: 'Mozambique in southern Africa: The challenges of the present: rethinking the Social Sciences', a conference held 'in memory of Ruth First, on the passage of 25 years since her assassination' at the CEA, 
17 August 2007. According to the occasion's announcement, 'Today, our country is particularly concerned with poverty, unemployment, social exclusion, construction of democracy and peace, participatory government, security and HIV/SIDA. Social scientists feel themselves bound to contribute their analyses to the construction of a democracy rooted in knowledge of the national, regional and African reality, in the process giving full weight to the local production of knowledge in the creation of a freer and more just societyé'. Ruth First, her bio-bibliography as well as her political trajectory - in the public sphere, as a forthright champion of African liberation and unrelenting reader of post-independence development; in her personal papers, as the critical, even acerbic at times, commentator on colleagues and curricula; as in her pedagogical practices, demanding, for example, that her students distinguish between 'growth' and 'development' - exemplifies that very 'teleological problematic' identified by de Braganca and Depelchin. As Joe Slovo, however, wrote in the somewhat more becalmed aftermath of his wife's only too precipitous demise:

In our orations we often try to try to mitigate the impact of such deathblows by emphasizing that the fallen will, through their very sacrifice, inspire an even greater advance of the cause for which they died. There is something in this long-term view, even though it can neither assuage personal anguish nor replenish political gaps. But there is a real sense in which our loss is not always the enemy's gain (Slovo 1988:8).

So then, for now, what can the university, even with all its 'discontents', again as then, here and there, do anyway, to 'replenish [those] political gaps'? A ‘teleological problematic'? Or?

\section{Notes}

1. This article is part of a longer, book-length, bio-bibliographical study in progress of Ruth First's life work, tentatively titled Looked Class, Talked Red: Ruth First and a Red-Lined Africa. The essay is a very preliminary attempt to consider Ruth First's pedagogical itinerary - Durham-Dar es Salaam-Maputo - as an intellectual trajectory that intersects with a larger African historical narrative. I want also to acknowledge the generous assistance from trustees and holders of Ruth First's papers, both at the Institute of Commonwealth Studies in London and at the University of Texas at Austin, as well as the eminently cordial collegiality and support of faculty and staff at the Centro de Estudos Africanos at the Universidade Eduardo Mondlane in Maputo.

2. References to materials relating to Ruth First's semester in Dar es Salaam are from the Ruth First Papers, held at the Institute of Commonwealth of Studies at the University of London: RF/1/14/6.

3. South West Africa (1963); 117 Days (1965); The Barrel of a Gun: Political Power and the Coup d'Etat (1970); The South African Connection: Western 
Investment in Apartheid (with Jonathan Steele and Christabel Gurney, 1972); Libya: The Elusive Revolution (1974); Olive Schreiner (with Ann Scott, 1980); Black Gold: The Mozambican Miner, Proletarian and Peasant (1983).

\section{References}

Centro de Estudos Africanos. Curso de Desenvolvimento - Notas de Ensino 1979-1983.

Centro de Estudos Africanos. Textos de Apoio (Curso de Desenvolvimento).

Centro de Estudos Africanos, 1982, Mozambican Studies/Estudos Mocambicanos, 1.

Cooper, F., 2005, Colonialism in Question: Theory, Knowledge, History, Berkeley and London: University of California Press..

Davidson, B., 1987, ‘Aquino de Braganca, 1928-86', Africa: Journal of the International African Institute, 57, 2.

De Braganca, A. and First, R., 1984, 'From Chibalo to the Liberation of South Africa', Mozambican Studies/Estudos Mocambicanos 2.

De Braganca, A. and Depelchin, J., 1986, 'From the Idealization of Frelimo to the Understanding of thRecent History of Mozambique', African Journal of Political Economy.

Depelchin, J., 2005, Silences in African History: Between the Syndromes of Discovery and Abolition, Dar es Salaam: Mkuki na Nyota,.

First, R., Ruth First Papers, Institute of Commonwealth Studies, University of London.

First, R. and de Braganca, A., 1981, 'Underdevelopment and Migrant Labour: Editorial', Mozambican Studies/Estudos Mocambicanos, 1

Kimambo, I., 1993, Three Decades of Production of Historical Knowledge at Dar es Salaam, Dar es Salaam: Dar es Salaam University Press.

Mamdani, M., 2007, Scholars in the Marketplace: The Dilemmas of Neo-Liberal Reform at Makerere University, 1989-2005, Dakar: CODESRIA,.

Mkude, D. Cooksey, B. and Levey, L., 2003, Higher Education in Tanzania, Partnership for Higher Education in Africa/Oxford: James Currey/Dar es Salaam: Mkuki na Nyota.

Mario, M., Fry, P., Levey, L.A and Chilundo, A., 2003, Higher Education in Mozambique, Partnership for Higher Education in Africa/Oxford: James Currey/ Maputo: Universidade Eduardo Mondlane.

Santos, B-d-S., 2006, 'The Heterogeneous State and Legal Pluralism in Mozambique', Law and Society Review 40, 1.

Shivji, I., 2006, Let the People Speak: Tanzania Down the Road to Neo-Liberalism, Dakar: CODESRIA.

Slovo, J., Introduction to Ruth First, 1988, 117 Days: An Account of Confinement and Interrogation under the South African Ninety-Day Detention Law (1965), London: Bloomsbury.

Wolpe, H., 1985, 'The Liberation Struggle and Research', Review of African Political Economy 32 (April). 
